\title{
FAKTOR-FAKTOR YANG MEMPENGARUHI PEMAHAMAN UMKM DALAM PENYAJIAN LAPORAN KEUANGAN BERDASARKAN SAK EMKM PADA UMKM DI KELURAHAN JAKASETIA
}

\author{
Delvin Kautsar ${ }^{1}$ \\ ${ }^{1}$ Fakultas Ekonomi Universitas Krisnadwipayana \\ Jalan Unkris Jatiwaringin Jakarta Timur \\ Dewi Rejeki $^{2}$ \\ ${ }^{2}$ Fakultas Ekonomi Universitas Krisnadwipayana \\ Jalan Unkris Jatiwaringin Jakarta Timur
}

\begin{abstract}
To find out how much the influence of the giving information and socialization, educational background, level of education, size of enterprises and enterprises long on the understanding of MSMes in drawing up financial statements based on the SAK EMKM. This research was carried out on 75 SMES in Jakasetia Sub-district using the questionnaire as a data retrieval method. Data was analyzed using multiple regression analysis that processed it through SPSS 25.0 application software The result of the t-test showed that the giving information and socialization, educational background, level of education, size of enterprises and enterprises long variables had a significant effect on the understanding of MSMes in drawing up financial statements based on the SAK EMKM. The conclusion of this study shows that the variable the giving information and socialization, educational background, level of education, size of enterprises and enterprises long has a significant effect on the understanding of MSMes in drawing up financial statements based on the SAK EMKM.
\end{abstract}

Keywords: SAK EMKM, Financial Statements, Understanding MSMEs

\section{PENDAHULUAN}

Perkembangan pembangunan di Indonesia dari segala bidang mulai mengalami peningkatan yang signifikan. Sesudah terjadinya krisis moneter di tahun 1998, pemerintah mulai bergerak untuk mengatur pembangunan di Indonesia. Perkembangan pembangunan yang terjadi di antaranya adalah bidang industri dan ekonomi. Peningkatan pembangunan di Indonesia tidak terlepas dari perusahaan-perusahaan yang ada di Indonesia. Perusahaanperusahaan di Indonesia baik perusahaan besar maupun UMKM sangat membantu untuk mengembangkan dunia industri dan ekonomi dalam negeri.
Usaha Mikro Kecil Menengah sudah berkembang dan tumbuh sebelum Indonesia merdeka. UMKM diatur pada Undang-Undang No. 20 Tahun 2008 tentang Usaha Mikro Kecil Menengah. Dengan adanya Undang-Undang tersebut maka usaha mikro kecil menengah memperoleh keadilan dan jaminan usaha, selain itu dapat juga meningkatkan potensi, kedudukan dan peran UMKM dalam mewujudkan pemerataan, ekonomi, dan penciptaan lapangan kerja, pengentasan kemiskinan, dan peningkatan pendapatan rakyat.

Seiring perkembangan yang terus meningkat, UMKM mengalami banyak masalah. Salah satu masalahnya adalah pemahaman pengelola UMKM yang kurang mengetahui pentingnya 
ISSN : 2406-7415

e-ISSN : 2655-9919

JURNAL AKUNTANSI DAN BISNIS KRISNADWIPAYANA

Vol. 7 No. 1 (Januari - April) 2020

DOI: http://dx.doi.org/10.35137/jabk.v7i1.375

penyusunan dan pencatatan laporan keuangan. Penyusunan dan pencatatan sangat diperlukan oleh pengelola UMKM untuk mengetahui kinerja perusahaan dan posisi keuangan yang relevan dan akurat.

Dengan adanya masalah ini, IAI (Ikatan Akuntansi Indonesia) membuat standar akuntansi khusus untuk usaha mikro kecil menengah agar pengelola UMKM dapat menyusun laporan keuangan yang relevan dan akurat. Tujuan IAI menyusun dan menerbitkan Standar Akuntansi Keuangan untuk Entitas Mikro Kecil dan Menengah (SAK EMKM) untuk menjadi pedoman bagi UMKM dalam membuat laporan keuangan.

Namun demikian masih banyak perusahaan UMKM yang belum melakukan penyusunan dan pencatatan laporan keuangan yang sesuai dengan SAK EMKM. Hal ini, karena ada beberapa faktor yang mempengaruhi pengelola UMKM dalam memahami SAK EMKM.

Faktor yang pertama adalah pemberian informasi dan sosialisasi. Pengelola UMKM yang mendapatkan informasi dan sosialisasi dengan baik maka pemahaman atas SAK EMKM akan menjadi lebih baik dan mendukung proses implementasi SAK EMKM tersebut dalam usahanya.

Faktor yang kedua adalah latar belakang pendidikan. Latar belakang pendidikan pada bagian akuntansi berpengaruh pada penyusunan dan pelaporan keuangan suatu UMKM. Latar belakang pendidikan akuntansi akan mempunyai persepsi yang baik mengenai SAK EMKM dibandingkan dengan berlatar belakang pendidikan non akuntansi.

Faktor yang ketiga adalah jenjang pendidikan. Jenjang pendidikan yang telah ditempuh oleh pengelola UMKM berpengaruh terhadap cara pandang mengenai wawasan maupun informasi baru yang berhubungan dengan kegiatan operasional termasuk dalam penyediaan informasi khususnya akuntansi yang sesuai dengan standar yang berlaku.

Faktor yang keempat adalah lama usaha. Lama usaha atau umur usaha menjadi salah satu pertimbangan dalam penilaian usaha baik investor maupun perbankan, sebab dari umur usaha ini dapat diketahui business stage dari usaha tersebut serta track record dari usaha yang dijalani selama ini. Umur usaha yang semakin panjang memberikan keuntungan dalam hal telah memiliki struktur dan proses yang mendisiplinkan setiap tindakan UMKM. Salah satunya adalah proses pembukuan.

Faktor yang kelima adalah ukuran usaha. Ukuran usaha dapat mempengaruhi pemikiran pengelola UMKM terkait semakin tingginya tingkat transaksi UMKM sehingga diharapkan dengan makin besarnya ukuran usaha maka dapat mendorong pengelola untuk belajar dan berpikir terkait solusi untuk menghadapinya.

Penelitan ini mengambil objek yaitu UMKM yang berada di Kelurahan Jakasetia, dikarenakan pesatnya perkembangan UMKM di Kelurahan ini. Sangat disayangkan jika UMKM yang berada di kelurahan Jakasetia tidak memahami adanya SAK EMKM. padahal dengan adanya SAK EMKM, dapat mempermudah pengelola UMKM dalam membuat penyusunan dan penyajian laporan keuangan. Dalam hal ini, peneliti membatasi penelitian ini dengan mengambil objek penelitian 75 UMKM dari 85 UMKM di Kelurahan Jakasetia Kecamatan Bekasi Selatan, 
DOI: http://dx.doi.org/10.35137/jabk.v7i1.375

dengan permasalahan yang diangkat adalah sebagai berikut :

1. Apakah Pemberian Informasi dan Sosialisasi berpengaruh terhadap pemahaman UMKM dalam menyusun laporan keuangan berdasarkan SAK EMKM pada UMKM di Jakasetia ?

2. Apakah Latar belakang pendidikan berpengaruh terhadap pemahaman UMKM dalam menyusun laporan keuangan berdasarkan SAK EMKM pada UMKM di Jakasetia?

3. Apakah Jenjang pendidikan berpengaruh terhadap pemahaman UMKM dalam menyusun laporan keuangan berdasarkan SAK EMKM pada UMKM di Jakasetia ?

4. Apakah lama usaha berpengaruh terhadap pemahaman UMKM dalam menyusun laporan keuangan berdasarkan SAK EMKM pada UMKM di Jakasetia?

5. Apakah ukuran usaha berpengaruh terhadap pemahaman UMKM dalam menyusun laporan keuangan berdasarkan SAK EMKM pada UMKM di Jakasetia?

\section{LANDASAN TEORI}

\section{Laporan Keuangan}

Laporan keuangan adalah laporan yang menunjukkan kondisi keuangan perusahaan pada saat ini atau dalam suatu periode tertentu, Kasmir (2016:7). Menurut PSAK No. 1 (2018:1), Laporan keuangan adalah penyajian terstruktur dari posisi keuangan dan kinerja keuangan suatu entitas.

Tujuan keseluruhan dari pelaporan keuangan adalah untuk memberikan informasi yang berguna bagi investor dan kreditur dalam pengambilan keputusan investasi dan kredit, Hery (2017:40). Menurut SAK EMKM (2018:2), Tujuan laporan keuangan adalah untuk menyediakan informasi posisi keuangan dan kinerja keuangan suatu entitas yang bermanfaat bagi sejumlah besar pengguna dalam pengambilan keputusan ekonomi oleh siapapun yang tidak dalam posisi dapat meminta laporan keuangan khusus untuk memenuhi kebutuhan informasi tersebut. Pengguna tersebut meliputi penyedia sumber daya bagi entitas seperti kreditor maupun investor. Dalam memenuhi tujuannya, laporan keuangan juga menunjukkan pertanggungjawaban manajemen atas sumber daya yang dipercayakan kepadanya.

\section{Standar Akuntansi Keuangan Entitas Mikro, Kecil, dan Menengah (SAK EMKM)}

\begin{tabular}{llr}
\multicolumn{1}{c}{ Menurut } & \multicolumn{1}{c}{ SAK } & EMKM \\
(2018:par9) menyatakan & bahwa \\
Laporan Keuangan minimum & terdiri \\
dari: & &
\end{tabular}

1. Laporan Posisi Keuangan

Laporan posisi keuangan menyajikan informasi tentang aset, liabilitas, dan ekuitas entitas pada akhir periode pelaporan. Laporan posisi keuangan entitas dapat mencakup akun-akun berikut :
a. Kas dan Setara Kas
b. Piutang
c. Persediaan
d. Aset Tetap 
DOI: http://dx.doi.org/10.35137/jabk.v7i1.375
e. Utang Usaha
f. Utang Bank
g. Ekuitas

2. Laporan Laba Rugi

Laporan laba rugi entitas dapat mencakup akun-akun sebagai berikut :
a. Pendapatan
b. Beban Keuangan
c. Beban Pajak

3. Catatan Atas Laporan Keuangan

Catatan atas laporan keuangan berisi tambahan dari rincian akunakun tertentu yang relevan. Catatan atas laporan keuangan memuat :

a. Suatu pernyataan bahwa laporan keuangan telah disusun sesuai dengan SAK EMKM

b. Ikhtisar kebijakan akuntansi

c. Informasi tambahan dan rincian akun tertentu yang menjelaskan transaksi penting dan material sehingga bermanfaat bagi pengguna untuk memahami laporan keuangan.

\section{Usaha Mikro, Kecil dan Menengah (UMKM)}

Menurut Undang-Undang Nomor 20 tahun 2008 pasal 1 ayat 1 disebutkan bahwa definisi Usaha Mikro yaitu usaha produktif milik orang perorangan dan atau badan usaha perorangan yang memenuhi kriteria Usaha Mikro sebagaimana diatur dalam UndangUndang ini.

Entitas tanpa akuntabilitas publik yang signifikan, sebagaimana didefinisikan dalam Standar Akuntansi Keuangan Entitas Tanpa Akuntabilitas Publik (SAK ETAP), yang memenuhi definisi dan kriteria usaha mikro, kecil, dan menengah sebagaimana diatur dalam peraturan perundang-undangan yang berlaku di Indonesia, setidaknya selama dua tahun berturut-turut, IAI dalam SAK EMKM (2018:1)

Faktor-faktor yang Mempengaruhi Pemahaman UMKM Dalam Menyusun Laporan Keuangan

\section{Informasi dan Sosialisasi}

Data yang dikelola dan diproses untuk memberikan arti dan memperbaiki proses pengambilan keputusan, Romney \& Steinbart (2015:4). Pemberian informasi dan sosialisasi merupakan cara atau metode untuk membantu dan mengenalkan UMKM. Dalam hal tersebut pemberian informasi dan sosialisasi adalah proses penerapan laporan keuangan yang membantu UMKM dalam membuat laporan keuangan untuk meningkatkan usahanya, Soekanto (2017).

\section{Latar Belakang Pendidikan}

Latar belakang pendidikan merupakan aspek terpenting di kehidupan, dan seringkali dijadikan sebagai tolak ukur dalam menilai kualitas suatu pelaku UMKM. Tolak ukur yang dimaksud adalah Pengetahuan Akuntansi, yaitu ilmu yang dimiliki seseorang dari suatu objek tentang keakuntansian.

\section{Jenjang Pendidikan}

Jenjang pendidikan adalah tahapan atau tingkatan yang mesti ditempuh berdasarkan kemampuan yang ingin dikembangkan, tujuan yang ingin dicapai, dan tingkat perkembangan dari peserta didik.

\section{Lama Usaha}

Lama usaha adalah lamanya seseorang menekuni usaha yang dijalankan. Lama usaha juga diartikan sebagai waktu yang dibutuhkan oleh suatu perusahaan 
DOI: http://dx.doi.org/10.35137/jabk.v7i1.375 untuk menunjukkan bahwa perusahaan tersebut mampu bersaing dalam pasar sehingga mempertahankan usahanya dan mencapai tujuan yang diinginkan.

\section{Ukuran Usaha}

Ukuran usaha adalah skala yang menunjukkan kecil atau besarnya suatu entitas atau perusahaan yang dapat diukur menggunakan beberapa cara. Cara yang dapat digunakan yaitu dilihat dari volume penjualan, nilat asset dan jumlah karyawan dari perusahan tersebut.

Kriteria jumlah karyawan berdasarkan jumlah karyawan atau tenaga kerja yang merupakan tolak ukur yang digunakan oleh Badang Pusat Stastik (BPS) untuk menilai usaha kecil atau besarnya seperti berikut :

a. Usaha Mikro : $<5$ orang

b. Usaha Kecil :5-19 orang

c. Usaha Menengah : $20-99$ orang

Dan seperti yang tertulis di Undang-Undang Nomor 20 Tahun 2008 bahwa ukuran usaha dapat dikelompokan dalam beberapa kategori, yaitu usaha mikro, usaha kecil, usaha menengah dan usaha besar.

\section{METODOLOGI PENELITIAN}

Objek dalam penelitian ini adalah Usaha Mikro, Kecil dan Menengah (UMKM) yang terdaftar di kelurahan Jakasetia, Bekasi Selatan. Populasi pada penelitian ini adalah Usaha Mikro, Kecil dan Menengah (UMKM) yang terdaftar di Kelurahan Jakasetia yaitu sejumlah 85 UMKM. Pemilihan sampel dilakukan dengan metode purposive sampling dengan kriteria UMKM yang dijadikan sampel dalam penelitian ini adalah sebagai berikut :

1. Usaha yang memiliki omzet per tahun Rp 0 s.d Rp 500.000.000 per tahun.

2. UMKM yang usahanya telah berdiri minimal 1 tahun.

3. UMKM yang terdaftar di Kelurahan Jakasetia, Kota Bekasi.

Dari 85 UMKM yang terdaftar di

Kelurahan Jakasetia, hanya 75 UMKM yang dapat dijadikan sebagai sampel dalam penelitian ini. Karena sesuai dengan kriteria yang peneliti tentukan.

Metode pengumpulan data yang digunakan dalam melakukan penelitian ini adalah observasi, wawancara dan kuesioner. Sedangkan teknik analisa data dengan menggunakan analisis statistikt deskriptif, uji kualitas data (uji validitas dan uji reliabitas), uji asumsi klasik (uji normalitas, uji multikolonieritas dan uji heteroskedasitas), analisis regresi berganda dan pengujian hipotesis (uji-t) dan Koefisien Determinasi $\left(\mathrm{R}^{2}\right)$.

\section{HASIL PENELITIAN}

\section{Karakteristik Responden}

\section{Jenis Kelamin}

Distribusi responden berdasarkan jenis kelamin dapat ditunjukkan oleh tabel dibawah ini : Tabel 1. Jenis Kelamin

\begin{tabular}{|l|l|l|}
\hline Jenis Kelamin & Jumlah & Persentase (\%) \\
\hline Laki - laki & 46 & 61,3 \\
\hline Perempuan & 29 & 38,7 \\
\hline Total & 75 & 100 \\
\hline
\end{tabular}


ISSN : 2406-7415

e-ISSN : 2655-9919

JURNAL AKUNTANSI DAN BISNIS KRISNADWIPAYANA

Vol. 7 No. 1 (Januari - April) 2020

DOI: http://dx.doi.org/10.35137/jabk.v7i1.375

Berdasarkan tabel diatas, diketahui bahwa mayoritas responden berjenis kelamin lakilaki yaitu sebanyak 46 responden atau $61,3 \%$, sedangkan responden berjenis kelamin perempuan sebanyak 29 responden atau $38,7 \%$.

2. Usia

Distribusi responden berdasarkan usia dapat ditunjukkan oleh tabel dibawah ini:

Tabel 2. Usia

\begin{tabular}{|l|l|l|}
\hline Usia & Jumlah & $\begin{array}{l}\text { Persentase } \\
(\%)\end{array}$ \\
\hline $\begin{array}{l}25 \text { Tahun - 35 } \\
\text { Tahun }\end{array}$ & 36 & 48,0 \\
\hline $\begin{array}{l}\text { 35 Tahun - 45 } \\
\text { Tahun }\end{array}$ & 21 & 28,0 \\
\hline$>45$ Tahun & 18 & 24,0 \\
\hline \multicolumn{3}{|c|}{ Berdasarkan tabel diatas, } \\
\hline \multicolumn{3}{|c|}{ bahwa mayoritas } \\
diketahui \\
responden berusia 25 Tahun - 35 \\
Tahun yaitu sebanyak 36 responden \\
atau 48\%. Sedangkan minoritas \\
responden berusia >45 Tahun yaitu \\
sebanyak 18 responden atau 24\%.
\end{tabular}

3. Kelengkapan usaha

Distribusi responden

berdasarkan kelengkapan usaha dapat ditunjukkan oleh tabel dibawah ini:

Tabel 3. Kelengkapan Usaha

\begin{tabular}{|l|l|l|}
\hline Usia & Jumlah & $\begin{array}{l}\text { Persentase } \\
(\%)\end{array}$ \\
\hline NPWP & 43 & 57,3 \\
\hline SIUP & 18 & 24,0 \\
\hline TDP & 14 & 18,7 \\
\hline & 75 & 100 \\
\hline
\end{tabular}

Berdasarkan tabel diatas, diketahui bahwa mayoritas responden mempunyai kelengkapan usaha berupa NPWP sebanyak 43 responden atau $57,3 \%$. Sedangkan minoritas responden mempunyai kelengkapan usaha berupa TDP sebanyak 14 responden atau $18,7 \%$.

\section{Analisis Deskriptif}

\section{Pemberian Informasi dan Sosialisasi (X1)}

Tanggapan responden

berdasarkan pemberian informasi dan sosialisasi (X1) dapat dilihat dari tabel dibawah ini :

Tabel 4. Pemberian Informasi dan

Sosialisasi

\begin{tabular}{|c|c|c|c|c|c|c|}
\hline No. & Indikator & \multicolumn{3}{|c|}{ Jawaban } & Jumlah & \\
\hline \multirow[t]{2}{*}{1.} & \multirow{2}{*}{$\begin{array}{l}\text { Memiliki Pengetahuan } \\
\text { sebelumnya terkait } \\
\text { SAK EMKM }\end{array}$} & $\mathrm{Ya}$ & \multicolumn{2}{|c|}{ Tidak } & & \\
\hline & & $\begin{array}{c}29 \\
38,7 \%\end{array}$ & \multicolumn{2}{|c|}{$\begin{array}{c}46 \\
61,3 \%\end{array}$} & $\begin{array}{c}75 \\
100 \%\end{array}$ & \\
\hline \multirow[t]{3}{*}{2.} & \multirow{3}{*}{$\begin{array}{l}\text { Mendapatkan } \\
\text { Informasi Terkait } \\
\text { SAK EMKM }\end{array}$} & \multicolumn{3}{|c|}{ Jawaban } & & \\
\hline & & Seminar & Pelatihan & Internet & Buletin & \\
\hline & & $\begin{array}{c}10 \\
13,3 \%\end{array}$ & $\begin{array}{c}18 \\
24 \%\end{array}$ & $\begin{array}{c}35 \\
46,7 \%\end{array}$ & $\begin{array}{c}12 \\
16 \%\end{array}$ & $\begin{array}{c}75 \\
100 \%\end{array}$ \\
\hline \multirow[t]{3}{*}{3.} & \multirow{3}{*}{$\begin{array}{l}\text { Mendapat } \\
\text { sosialisasi atau } \\
\text { pelatihan tentang } \\
\text { SAK EMKM }\end{array}$} & \multicolumn{3}{|c|}{ Jawaban } & & \\
\hline & & Ya & \multicolumn{2}{|c|}{ Tidak } & & \\
\hline & & $\begin{array}{c}27 \\
36 \%\end{array}$ & \multicolumn{2}{|c|}{$\begin{array}{c}48 \\
64 \%\end{array}$} & $\begin{array}{c}75 \\
100 \%\end{array}$ & \\
\hline
\end{tabular}

Berdasarkan tabel diatas,

indikator memiliki pengetahuan sebelumnya terkait SAK EMKM mayoritas menjawab tidak sebanyak 46 responden atau $61,3 \%$. Indikator mendapatkan informasi terkait SAK EMKM mayoritas responden menjawab melalui internet sebanyak 35 responden atau $46,7 \%$. Indikator mendapatkan sosialisasi atau pelatihan tentang SAK EMKM mayoritas responden menjawab tidak sebanyak 48 responden atau $64 \%$.

\section{Latar Belakang Pendidikan (X2)} Tanggapan responden berdasarkan latar belakang pendidikan (X2) dapat dilihat dari tabel dibawah ini :

Tabel 5. Latar Belakang Pendidikan

\begin{tabular}{|l|l|c|c|}
\hline No. & Indikator & $\mathrm{F}$ & $\%$ \\
\hline 1. & $\begin{array}{c}\text { Latar belakang } \\
\text { SMA }\end{array}$ & 39 & $52 \%$ \\
\hline 2. & $\begin{array}{c}\text { Manajemen dan } \\
\text { Ekonomi }\end{array}$ & 20 & $26,7 \%$ \\
\hline 3. & $\begin{array}{c}\text { Pendidikan } \\
\text { Akuntansi }\end{array}$ & 16 & $21,3 \%$ \\
\hline & \multicolumn{2}{|c|}{75} & $100 \%$ \\
\hline
\end{tabular}


ISSN : 2406-7415

e-ISSN : 2655-9919

JURNAL AKUNTANSI DAN BISNIS KRISNADWIPAYANA

Vol. 7 No. 1 (Januari - April) 2020

DOI: http://dx.doi.org/10.35137/jabk.v7i1.375

Berdasarkan tabel diatas, mayoritas responden memiliki latar belakang pendidikan SMA sebanyak 39 responden atau 52\%, selanjutnya latar belakang pendidikan akuntansi sebanyak 16 responden atau $21,3 \%$.

\section{Jenjang Pendidikan (X3)}

Tanggapan berdasarkan jenjang responden (X3) dapat dilihat dari dibawah ini:

Tabel 6.Jenjang Pendidikan

\begin{tabular}{|l|l|c|c|}
\hline No. & Indikator & $\mathrm{F}$ & $\%$ \\
\hline 1. & SD/SMP & 0 & $0 \%$ \\
\hline 2. & SMA & 44 & $58,7 \%$ \\
\hline 3. & Diploma & 22 & $29,3 \%$ \\
\hline 4. & $\begin{array}{c}\text { Sarjana } \\
\text { Pascasarjana }\end{array}$ & 9 & $12 \%$ \\
\hline \multicolumn{3}{|c|}{ Berdasarkan tabel diatas, } \\
\hline
\end{tabular}
mayoritas responden yang memiliki jenjang pendidikan SMA sebanyak 44 responden atau $58,7 \%$, Sarjana/Pascasarjana sebanyak 9 responden atau 12\%, Diploma sebanyak 22 responden atau $29,3 \%$.

\section{Lama Usaha (X4)}

Tanggapan responden berdasarkan lama usaha (X4) dapat dilihat dari tabel dibawah ini:

Tabel 7. Lama Usaha

\begin{tabular}{|l|l|c|c|}
\hline No. & Indikator & $\mathrm{F}$ & $\%$ \\
\hline 1. & 1 tahun & 27 & $36 \%$ \\
\hline 2. & $\begin{array}{c}1 \text { tahun }-3 \\
\text { tahun }\end{array}$ & 31 & $41,3 \%$ \\
\hline 3. & $>3$ tahun & 17 & $22,7 \%$ \\
\hline & & 75 & $100 \%$ \\
\hline
\end{tabular}

Berdasarkan tabel diatas, mayoritas responden menjawab 1 tahun - 3 tahun sebanyak 31 responden atau $41,3 \%$, kemudian yang menjawab $>3$ tahun sebanyak 17 responden atau $22,7 \%$, dan terakhir yang menjawab 1 tahun sebanyak 27 responden atau $36 \%$.

\section{Ukuran Usaha (X5)}

Tanggapan

responden berdasarkan ukuran usaha (X5) dapat dilihat dari tabel dibawah ini :

a) Jumlah Karyawan

Tabel 8. Jumlah Karyawan

\begin{tabular}{|l|l|c|c|}
\hline No. & Indikator & $\mathrm{F}$ & $\%$ \\
\hline 1. & $<4$ orang & 38 & $50,7 \%$ \\
\hline 2. & 5-19 orang & 37 & $49,3 \%$ \\
\hline 3. & 20-99 orang & 0 & 0 \\
\hline 4. & $>100$ orang & 0 & 0 \\
\hline & & 75 & $100 \%$ \\
\hline
\end{tabular}

Berdasarkan tabel

diatas, bahwa jumlah karyawan sebanyak $<4$ orang sebesar 38 responden atau $50,7 \%$. Kemudian jumlah karyawan sebanyak 5-19 orang sebanyak 37 responden atau 49,3\%.

b) Nilai Aset

Tabel 9. Nilai Aset

\begin{tabular}{|l|l|c|c|}
\hline No. & Indikator & $\mathrm{F}$ & $\%$ \\
\hline 1. & <Rp. 100 juta & 50 & $66,7 \%$ \\
\hline 2. & $\begin{array}{l}\text { Rp. 100 juta }- \\
\text { Rp. 499 } \\
\text { juta }\end{array}$ & 25 & $33,3 \%$ \\
\hline 3. & $\begin{array}{c}\text { Rp. 500 juta - } \\
\text { Rp. 2,5 } \\
\text { miliar }\end{array}$ & 0 & 0 \\
\hline 4. & $\begin{array}{c}\text { >Rp. 2,5 } \\
\text { miliar }\end{array}$ & 0 & 0 \\
\hline & \multicolumn{3}{|c|}{ Berdasarkan } \\
\hline
\end{tabular}

Berdasarkan tabel diatas, bahwa mayoritas UMKM mempunyai nilai asset sebesar <Rp. 100 juta sebanyak 50 responden atau $66,7 \%$. Kemudian nilai asset Rp. 100 juta - Rp. 499 juta sebanyak 25 responden atai $33,3 \%$.

c) Omzet Usaha

Tabel 10. Omzet Usaha

\begin{tabular}{|l|l|c|c|}
\hline No. & Indikator & F & $\%$ \\
\hline 1. & $<$ Rp. 100 juta & 47 & $62,7 \%$ \\
\hline 2. & $\begin{array}{l}\text { Rp. 100 juta }- \\
\text { Rp. 499 } \\
\text { juta }\end{array}$ & 28 & $37,3 \%$ \\
\hline
\end{tabular}


DOI: http://dx.doi.org/10.35137/jabk.v7i1.375

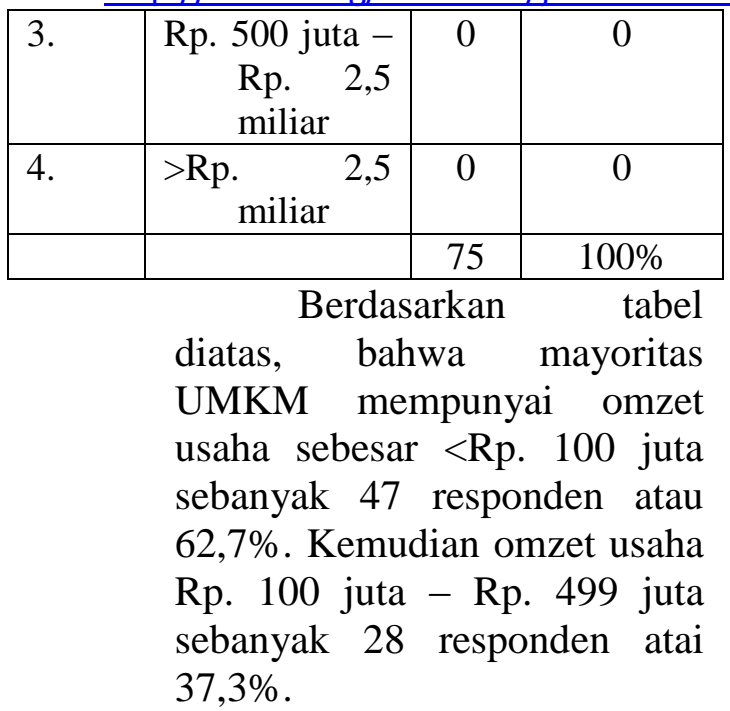

\section{Pemahaman SAK EMKM (Y)}

Tanggapan responden berdasarkan pemahaman SAK EMKM (Y) dapat dilihat dari tabel dibawah ini :

Tabel 11. Pemahaman tentang SAK EMKM

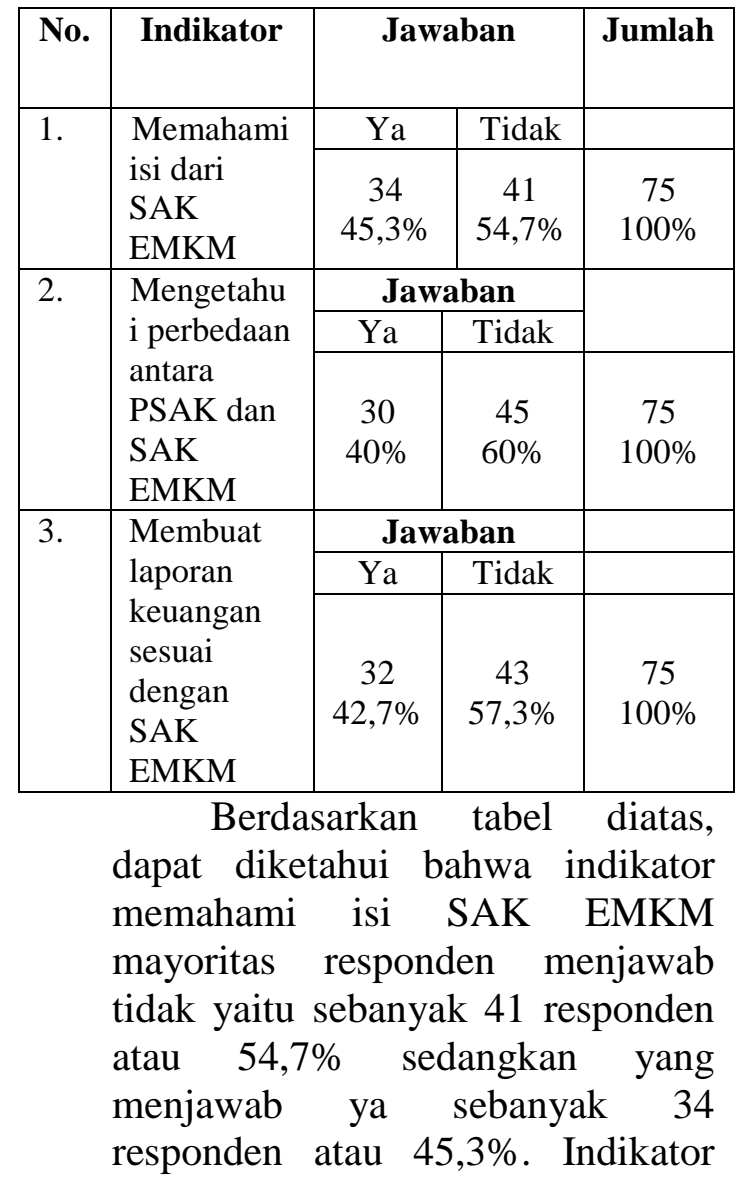

mengetahui perbedaan antara PSAK dan SAK EMKM mayoritas menjawab tidak yaitu sebanyak 45 responden atau $60 \%$ sedangkan yang menjawab ya sebanyak 30 responden atau 40\%. Indikator membuat laporan keuangan sesuai dengan SAK EMKM mayoritas menjawab tidak yaitu sebanyak 43responden atau $57,3 \%$ sedangkan yang menjawab ya sebanyak 32 responden atau $42,7 \%$.

\section{PEMBAHASAN}

Berdasarkan hasil penelitian yang dihasilkan oleh SPSS, maka dapat dibuat suatu penjelasan melalui interprestasi dengan membandingkan penelitian terdahulu. Adapun interprestasi dalam penelitian ini yang dapat dijelaskan sebagai berikut :

\section{Pengaruh Pemberian Informasi dan Sosialisasi terhadap pemahaman UMKM dalam Penyajian Laporan Keuangan berdasarkan SAK EMKM}

Hasil pengujian hipotesis yang dilakukan menunjukkan bahwa terdapat pengaruh secara parsial (uji t) antara pemberian informasi dan sosialisasi terhadap pemahaman SAK EMKM yang dilihat dari nilai $\mathrm{t}$ hitung yang lebih besar dari nilai $\mathrm{t}$ tabel.

Hasil penelitian ini didukung dengan penelitian yang dilakukan oleh Hidayah dan Restu (2019) yang menyatakan bahwa pemberian informasi dan sosialisasi berpengaruh positif terhadap tingkat pemahaman SAK EMKM. Hasil yang sama juga didapatkan oleh Purwaningsih, Devi dan 
ISSN : 2406-7415

e-ISSN : 2655-9919

JURNAL AKUNTANSI DAN BISNIS KRISNADWIPAYANA

Vol. 7 No. 1 (Januari - April) 2020

DOI: http://dx.doi.org/10.35137/jabk.v7i1.375

Tjahjono (2018) yang menyatakan bahwa pemberian informasi dan sosialisasi berpengaruh positif terhadap pemahaman SAK EMKM.

Pemberian informasi dan sosialisasi mengenai aturan SAK EMKM oleh pihak eksternal UMKM, baik instansi dan lembaga yang diyakini mampu memberikan pengetahuan bagian akuntansi untuk melakukan pemahaman yang lebih baik mengenai SAK EMKM sehingga bisa mendorong bagian akuntansi UMKM untuk mengambil keputusan terhadap penyesuaian aturan dan standar SAK EMKM tersebut dalam penyajian laporan keuangannya.

Dalam pemberian informasi dan sosialisasi, walaupun mayoritas responden tidak memiliki pengetahuan sebelumnya terkait dengan SAK EMKM tapi mayoritas responden mendapatkan informasi terkait SAK EMKM melalui internet.

2. Pengaruh Latar Belakang Pendidikan terhadap pemahaman UMKM dalam Penyajian Laporan Keuangan berdasarkan SAK EMKM

Hasil pengujian hipotesis yang dilakukan menunjukkan bahwa terdapat pengaruh secara parsial (uji t) antara latar belakang pendidikan terhadap pemahaman SAK EMKM yang dilihat dari nilai $t$ hitung yang lebih besar dari nilai $t$ tabel.

Hasil penelitian ini didukung dengan penelitian yang dilakukan oleh Yogi, Andwiani dan Fatmasari (2019) yang menyatakan bahwa latar belakang pendidikan berpengaruh positif terhadap pemahaman SAK EMKM.

Pengelola UMKM yang berlatar pendidikan non akuntansi cenderung lebih lama dalam memahami proses penyajian laporan keuangan berdasarkan SAK EMKM. Oleh karena itu, bagian akuntansi UMKM yang berlatar belakang pendidikan akuntansi memiliki pemahaman yang lebih baik daripada bagian akuntansi yang berlatar belakang pendidikan non akuntansi.

3. Pengaruh Jenjang Pendidikan terhadap pemahaman UMKM dalam Penyajian Laporan Keuangan berdasarkan SAK EMKM

Hasil pengujian hipotesis yang dilakukan menunjukkan bahwa terdapat pengaruh secara parsial (uji t) antara jenjang pendidikan terhadap pemahaman SAK EMKM yang dilihat dari nilai $t$ hitung yang lebih besar dari nilai t tabel.

Hasil penelitian ini didukung dengan penelitian yang dilakukan oleh Budi dan Rustam (2016) yang menyatakan bahwa jenjang pendidikan berpengaruh positif terhadap pemahaman SAK EMKM. Hasil yang sama juga didapatkan oleh Purwaningsih, Devi dan Tjahjono (2018) yang menyatakan bahwa jenjang pendidikan berpengaruh positif terhadap pemahaman SAK EMKM.

Semakin tinggi jenjang pendidikan yang ditempuh oleh pengelola UMKM, maka pemahaman pengelola UMKM terhadap SAK EMKM akan meningkat. Karena individu dengan jenjang pendidikan yang semakin tinggi akan lebih mudah dalam memahami yang baru. dibandingkan dengan pemilik 
DOI: http://dx.doi.org/10.35137/jabk.v7i1.375

UMKM yang mempunyai tingkat pendidikan yang lebih rendah. Tingkat pendidikan formal yang rendah cenderung membuat pemilik UMKM kurang begitu memahami SAK EMKM.

4. Pengaruh Lama Usaha terhadap pemahaman UMKM dalam Penyajian Laporan Keuangan berdasarkan SAK EMKM

Hasil pengujian hipotesis yang dilakukan menunjukkan bahwa terdapat pengaruh secara parsial (uji t) antara lama usaha terhadap pemahaman SAK EMKM yang dilihat dari nilai t hitung yang lebih besar dari nilai t tabel.

Hasil penelitian ini didukung dengan penelitian yang dilakukan oleh Ita Anggraeni (2018) yang menyatakan bahwa lama usaha berpengaruh positif terhadap pemahaman SAK EMKM.

Lama usaha atau umur usaha dalam hal ini merupakan lamanya suatu UMKM berdiri atau umur UMKM semenjak usaha tersebut berdiri sampai pada saat peneliti melakukan penelitian. Lama berdirinya suatu usaha menjadi salah satu faktor dalam penilaian suatu usaha baik oleh investor maupun perbankan.

Karena lama usaha dapat diketahui track record dari usaha tersebut dan juga business stage dari usaha yang dijalani selama ini. Umur usaha yang semakin lama atau panjang akan memberi keuntungan dalam struktur dan proses yang mendisiplinkan setiap tindakan suatu usaha. Salah satu prosesnya adalah proses pembukuan.

\section{Pengaruh Ukuran Usaha terhadap pemahaman UMKM dalam Penyajian Laporan Keuangan berdasarkan SAK EMKM}

Hasil pengujian hipotesis yang dilakukan menunjukkan bahwa terdapat pengaruh secara parsial (uji t) antara ukuran usaha terhadap pemahaman SAK EMKM yang dilihat dari nilai t hitung yang lebih besar dari nilai t tabel.

Hasil penelitian ini didukung dengan penelitian yang dilakukan oleh Nababan dan Angela (2019) yang menyatakan bahwa ukuran usaha berpengaruh positif terhadap pemahaman SAK EMKM. Hasil yang sama juga didapatkan oleh Ketut, Eka dan Nyoman (2018) yang menyatakan bahwa ukuran usaha berpengaruh positif terhadap pemahaman SAK EMKM.

Ukuran usaha merupakan hal yang tidak bisa lepas dari lingkungan pengelola UMKM. Ukuran usaha bisa mempengaruhi pendapat pengelola terkait semakin tingginya tingkat transaksi dan kompleksitas suatu usaha sehingga dapat diharapkan makin besarnya ukuran usaha dapat mendorong pengelola untuk belajar dan berpikir tentang solusi untuk menghadapinya. Ukuran usaha yang besar dapat teridentifikasi mempunyai karyawan dengan keahlian yang baik dan sumber daya yang lebih besar juga. 
DOI: http://dx.doi.org/10.35137/jabk.v7i1.375

\section{KESIMPULAN DAN SARAN}

\section{Kesimpulan}

1. Pemberian informasi dan sosialisasi berpengaruh signifikan positif terhadap pemahaman UMKM dalam menyusun laporan keuangan berdasarkan SAK EMKM diterima. Karena semakin banyak pemberian informasi dan sosialiasi tentang pemahaman SAK EMKM yang dilakukan oleh pihak eksternal maka akan mendorong UMKM khususnya bagian akuntansinya untuk mengambil keputusan terhadap penyesuaian aturan dan standar SAK EMKM dalam penyajian laporan keuangannya.

2. Latar belakang pendidikan berpengaruh signifikan positif terhadap pemahaman UMKM dalam menyusun laporan keuangan berdasarkan SAK EMKM diterima. Karena pengelola UMKM yang berlatar belakang akuntansi cenderung lebih cepat memahami proses penyajian laporan keuangan berdasarkan SAK EMKM dibandingkan pengelola UMKM yang berlatarkan non akuntansi.

3. Jenjang pendidikan berpengaruh signifikan positif terhadap pemahaman UMKM dalam menyusun laporan keuangan berdasarkan SAK EMKM diterima. Karena semakin tinggi jenjang pendidikan yang ditempuh oleh pengelola UMKM maka pemahaman SAK EMKM akan meningkat disebabkan individu dengan jenjang pendidikan yang semakin tinggi akan lebih mudah dalam memahami hal yang baru.

4. Lama usaha berpengaruh signifikan positif terhadap pemahaman
UMKM dalam menyusun laporan keuangan berdasarkan SAK EMKM diterima. Karena semakin lama usaha yang tempuh UMKM maka semakin besar tingkat transasksi dan kompleksitas suatu usaha sehingga dapat mendorong pengelola untuk belajar dan berpikir tentang solusi untuk menghadapinya khususnya tentang pembukuan.

5. Ukuran usaha berpengaruh signifikan positif terhadap pemahaman UMKM dalam menyusun laporan keuangan berdasarkan SAK EMKM diterima. Karena semakin besar suatu ukuran usaha yang dimiliki UMKM dapat mempengaruhi pendapatan pengelola terkait semakin tingginya tingkat transaksi dan kompleksitas suatu usaha sehingga dapat diharapkan makin besarnya ukuran usaha dapat mendorong pengelola untuk belajar dan berpikir tentang solusi untuk menghadapinya khususnya tentang pembukuan.

\section{Saran}

Berdasarkan hasil penelitian yang dikemukakan terdapat beberapa hal yang bisa disarankan oleh peneliti antara lain:

1. Untuk UMKM di Kelurahan Jakasetia dapat mengembangkan kemampuan teknis dalam menyusun dan mengolah laporan keuangan sesuai dengan standar akuntansi yang berlaku, sehingga pengelola UMKM di Kelurahan Jakasetia tidak hanya fokus dalam pengembangan penjualan dan pendapatannya saja tetapi juga mengembangkan pengelolaan keuangannya agar dapat lebih 
DOI: http://dx.doi.org/10.35137/jabk.v7i1.375 akurat dalam mengambil keputusan untuk menilai keberlangsungan usahanya.

2. Untuk lembaga eksternal atau pemerintah melakukan pelatihan, sosialisasi dan pemantauan secara berkala untuk menumbuhkan kesadaran bagi pengelola usaha mikro, kecil, dan menengah bahwa penerapan SAK EMKM dalam penyajian laporan keuangan adalah hal yang bermanfaat dan penting. Diharapkan juga untuk pemerintah agar terus mendorong semua UMKM yang ada di Indonesia agar terus belajar dan meningkatkan pemahaman melalui teknologi internet.

3. Untuk peneliti selanjutnya agar memperluas cakupan daerah penelitiannya, misalnya UMKM di kelurahan atau kecamatan lain yang lebih luas. Melakukan survey awal untuk menentukan objek yang akan dijadikan objek penelitian supaya ketika proses pengambilan data berlangsung tidak ada kendala dan sesuai dengan kriteria. Sehingga peneliti dapat lebih optimal dalam mendapatkan data penelitian.

\section{DAFTAR PUSTAKA}

Ghozali, Imam, 2018, Aplikasi Analisis Multivariate dengan Program IBM SPSS 25. Edisi 9, Semarang : Badan Penerbit Universitas Diponegoro
Hery. 2017, Teori Akuntansi (Pendekatan konsep dan analisis), Jakarta: PT. Grasindo.

Ikatan Akuntansi Indonesia. 2018. Pernyataan Standar Akuntansi Indonesia (PSAK) No 1 : Penyajian Laporan Keuangan. Jakarta: IAI

Ikatan Akuntan Indonesia. 2018. Standar Akuntansi Keuangan Entitas Mikro Kecil dan Menengah. Jakarta : Dewan Standar Akuntansi Keuangan Indonesia

Kasmir. 2016, Analisis Laporan Keuangan, Jakarta: PT Raja Grafindo Persada.

Romney Marshall \& Steinbart Paul, 2015, Sistem Informasi Akuntansi, Edisi 13, Jakarta, Salemba Empat

Sanusi Anwar, 2017, Metodologi Penelitian Bisnis, Jakarta : Salemba Empat

Soerjono Soekanto, 2017, Sosiologi Suatu Pengantar, Edisi Revisi, Jakarta, Rajawali Pers

Sugiyono, 2017, Metodologi Penelitian

Manajemen, Bandung : Alfabeta

Undang-Undang Republik Indonesia Nomor 20 Tahun 2008, Tentang

Usaha Mikro, Kecil, dan Menengah

Undang-Undang Sisdiknas No 20 Tahun 2003, Tentang Jenjang Pendidikan Formal

Wijaya David, 2018, Akuntansi UMKM, Yogyakarta, Gavamedia 